Вісник Національного університету “Львівська політехніка”. Серія "Проблеми економіки та управління"

№ 2(8), 2020

УДК 338.2:314.7

JEL Classification Code C21

L. I. Halkiv, L. M. Prokopyshyn-Rashkevych

Lviv Polytechnic National University,

Management of Organizations Department

\title{
MIGRATION MANAGEMENT: ANALYTICAL AND STATISTICAL DATA ON MIGRATION IN UKRAINE
}

http://doi.org/10.23939/semi2020.02.008

(C) Halkiv L. I., Prokopyshyn-Rashkevych L. M., 2020

The authors reveal the importance of migration management and its role in shaping effective migration policy. The structure of migration management is identified and the main stages of the national migration movement of the population are outlined. Despite the complexity of finding relevant statistics on migration in Ukraine, some key statistical indicators, including geographical and age structure of immigrants have been presented in this research work. in Ukraine.

Key words: migration, migration management, immigration statistics, migration policy

\section{Problem statement}

At the end of the twentieth century scientists have realized the need to develop joint management decisions aimed at controllability, predictability and usefulness of migration processes. Migration management is a new scientific direction that was formed at the junction of the migration science and the science of management. Due to its novelty, the topic of migration management requires further research. In particular, there is a need to determine migration management and the main features of national migration in Ukraine.

\section{Analysis of recent research and publications}

Despite the fact that the practice of migration management has a long history, the scientific discourse on migration management has intensified in recent decades. B. Gosh, Held Tobias, Conrad Christian, L. Sukhorukova, F. Hollifield carried out research in this field. Domestic scientists consider migration management issues mainly in the study of migration policy (O. Grechko [1], O. Rindzak [2], U. Sadova [3], R. Stakanov [4]).

The theory of migration management is being developed as an interdisciplinary field of research. In particular, representatives of pedagogy implement the research program "Migration Management in Education" [5, p. 12]. From the standpoint of the global economy, migration management can be positioned as a separate module (part of global management). James F. Hollifield considers the issue of migration management in the context of public administration [6]. As a tool to prevent hazards, migration management is studied in the framework of security and risk. Migration management is also considered as a new branch of regional economy and territorial management, designed to study the patterns and features of the response of public authorities and territorial administration to intensify migration processes, taking into account their socio-cultural and other consequences for local regions [3, p. 88].

\section{Setting objectives}

The core objectives of this article are to determine the features of migration management and identify the main stages of the national migration movement of the population in Ukraine. 


\section{Migration management: analytical and statistical data on migration in Ukraine}

\section{Presentation of the main results}

The IOM Glossary gives the following interpretation of migration management: "Various state functions within the national system aimed at humane and orderly management of cross-border migration, including management of entry and stay of foreigners inside the country, protection of refugees and others in need of protection" [7]. Migration management should provide a planned approach to policy development, legislative and administrative solutions to major migration issues.

American scientist B. Gosh initiated the development of a new concept of migration management. This concept is based on the thesis that well-managed migration can have a positive impact on countries of origin, destination and for migrants themselves. The structure of this concept includes three components: actors (subjects), practices and discourses [8]. The first component includes international organizations that influence the formation of state migration policy (IOM, ICMPD, UNHCR, Frontex, etc.). These organizations differ significantly from each other and have different status. However, all of them in some way influence the formation of global migration management. Some management functions in the field of labor migration are performed by the ILO; World Bank, WTO, etc. At the state level, the key actors in the management of immigration flows are the Ministries of Labor and Employment, as well as security and control institutions. The second component covers institutions that combat trafficking in human beings, as well as the training of civil servants in transit and labor-donor countries, and the development of migration policies in countries where there is no strategy in this area. The third component is related to conducting discourses. Global political discourse aims to shape the way migration is perceived by those responsible for managing it. For example, organizations such as the IOM form an objective perception of reality by covering the problems of illegal migration and human trafficking. Another aspect is the production of knowledge that legitimizes migration management. Such knowledge depends on scientists who work for international organizations as consultants [2, p. 48]. Migration management also acts as a market system in order to solve problems related to population migration, where states can buy a solution [8]. It is about how the governments can receive recommendations and scenarios of a migration policy from the international organizations on the basis of research spent in these states. The report of the Global Commission on International Migration [9] describes international responsibilities for migration management as "diffusion", so as a significant number of UN agencies and other organizations have responsibilities to manage certain aspects of international migration, but there is no single body that can contribute to a common global approach on migration regulation.

The study of migration processes is depicted in the research work of scientists and is the subject of activities of the International Organization for Migration (IOM), the International Labor Organization (ILO), the International Committee on Migration, the World Health Organization. Many Ukrainian scientists consider migration processes, focusing on the negative impact of emigration on the labor market in Ukraine. Huge challenges of migration and its impact on the Ukrainian economy was identified by O. Malinovskaya, N. Fedirko, I. Nesterova, B. Dmitruk, V. Chorna, O. Rovenchak and O. Petroye. Some research papers were dedicated to statistics data and an overview of the most prevailing migration trends. However, the main stages of the national migration movement of the population and immigration changes have not been fully addressed. At the same time, the number of immigrants in Ukraine has increased in recent years. Therefore, it is worth identifying the main causes and features of immigration in Ukraine.

Due to the fact that over 18 years have passed since the last census of Ukraine, it is not possible to properly assess parameters of the immigration process. The statistics of this process is maintained by various institutions (State Statistics Service, State Migration Service, State Border Guard Service, State Employment Service, Ministry of Social Policy, Ministry of Education and Science), operated by different agencies (Ministry of Internal Affairs, State Fiscal Service of Ukraine, Pension Fund, State Judicial Administration). However, the cooperation and coordination between ministries and agencies in the field of immigration statistics is low and the coverage of immigrants with available sources of information is incomplete.

The problem of estimating the number of immigrants is typical for Ukraine, like for a number of other countries. In general, immigrants can be divided into three groups (the number of immigrants in 


\section{I. Halkiv, L. M. Prokopyshyn-Rashkevych}

groups increases with increasing the order number): 1 - seek international protection, refugee status; 2 apply for stay legalization, that is, for temporary or permanent residence or long-term resident status (intend to move to Ukraine or extend their stay longer than the previously granted visa permits); 3 represent typical economic migration, including seasonal migration.

The State Statistics Service of Ukraine determines the number of arrivals (departed) according to the information on the registration (withdrawal from registration) of the individuals' place of residence. That is, the registration of immigrants is conducted by the year of residence registration, not by the year of arrival in Ukraine. Analyzing the dynamics of migration growth (reduction) after Ukraine gained independence (Fig. 1-3), the main stages of the national migration movement of the population can be outlined:

Stage I (1990-1993). Migration changes prolonged by the Soviet system. Predominance of intellectual and cultural elite in the external migration. The migration surplus was mainly caused by the resettlement of families from the USSR republics seeking to link their future to the Ukrainian state.

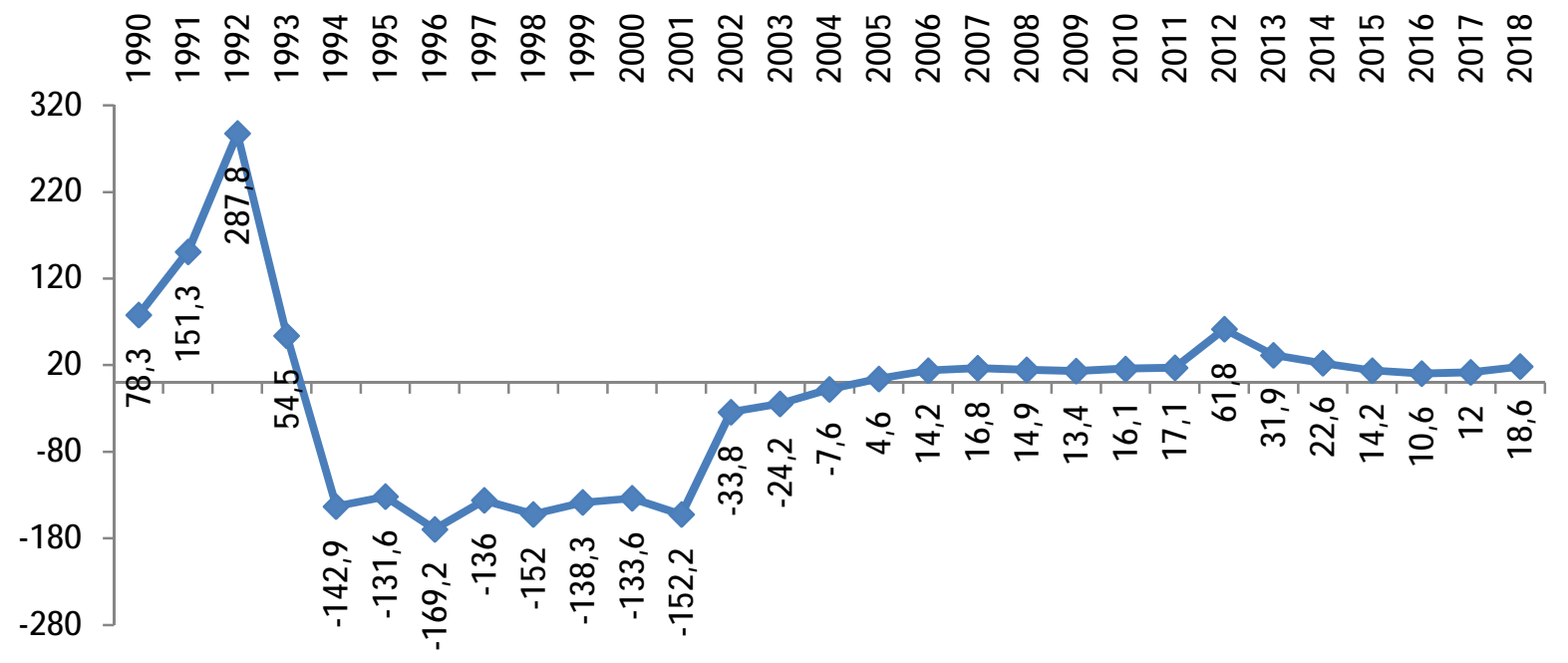

Fig. 1. Migration increase, reduction (-) in Ukraine during 1990-2018, thousand people [16]

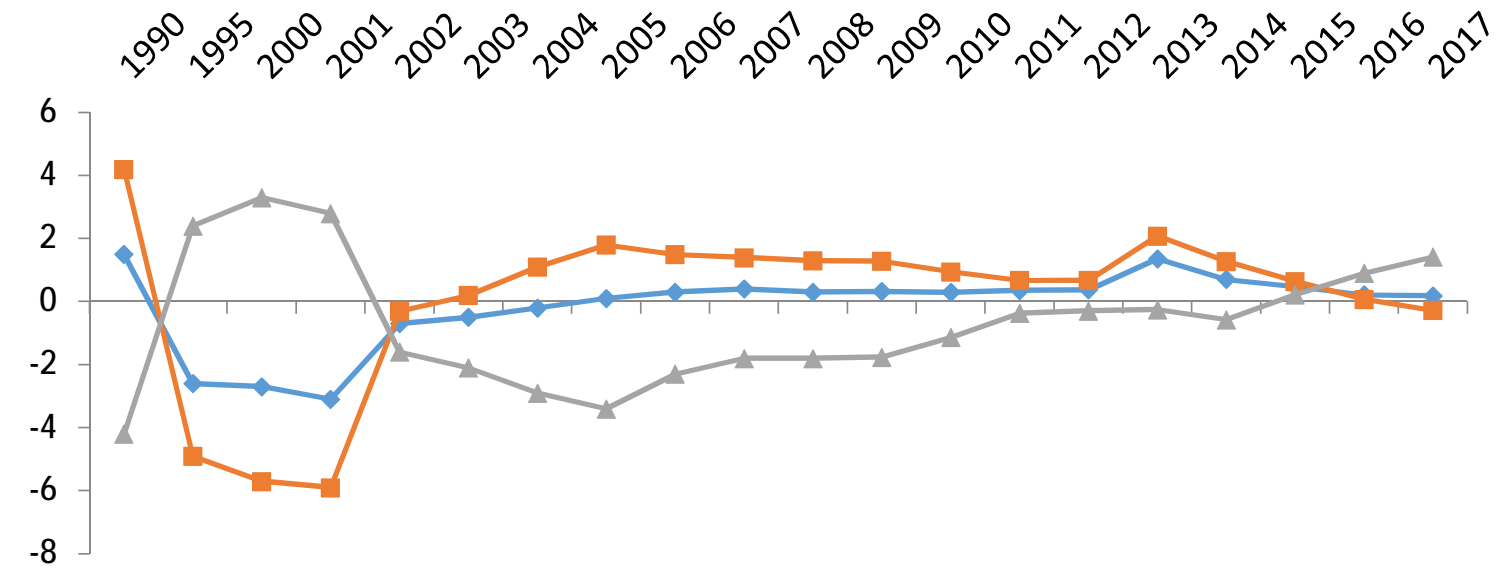

$\rightarrow$ Urban settlements and rural areas $\rightarrow$-Urban settlements $\rightarrow$ Rural areas

Fig. 2. Migration increase, reduction (-) per 1,000 people of the present population of Ukraine in 1990, 1995, 2000-2017 by types of settlements [17]

Stage II (1994-2001). Maximum cutbacks on migration caused mainly by the expansion of contacts with the states of "old" foreign countries, the emergence of a flow of permanent emigration from Ukraine to Europe, America, as well as to Israel. Outflow of higher education professionals, skilled workers and young people, mainly from urban areas. 


\section{Migration management: analytical and statistical data on migration in Ukraine}

Stage III (2002-2004). Increase in urban inflows in contrast to reduction in rural inflows. Expansion of the geography of external migration, strengthening of inter-regional differences in migration balance levels.

Stage IV (2005-2012). Slowdown in the rate of the change of migration movements. Changing the sign of the inter-state migration balance from negative to positive. The rapid increase in the migration growth indicator in 2012 is explained by the facilitation of the registration of foreigners that arrived in Ukraine in the previous years after the adoption of the Law of Ukraine "On the Legal Status of Foreigners and Stateless Persons" [18].

Stage V (2013-2014). Increased migration growth due to a large number of inflows from abroad to urban settlements.

Stage VI (after 2014). Slowdown in the rate of the change of the immigration flow increase, its reorientation to rural settlements.

By 2014, the migration balance across the country had coincided with the balance of inter-state migration. Since the beginning of persons' resettlement as a result of Russia's aggression, the inter-state population growth has been inferior to the overall migration increase in the country (in $2014-$ by 1.5 thousand people, in 2015 - by 5.0 thousand people, in 2016 - by 2.9 thousand people, 2018 - by 3.9 thousand people).

The majority of people have come to Ukraine from Europe (Table 1, Fig. 3). For the period 2002-2017, this number amounted to more than 630.0 thousand people. The European continent's share of immigrants averaged $55.9 \%$ in that period, fluctuating from $31.0 \%$ to $69.8 \%$ and generally showing a downward trend. Asia had a second place because of volume of arrival. This continent's immigration flow averaged 36.8, revealing an overall upward trend. Africa and America gained third and fourth place respectively. From these continents more than 45 thousand people came to Ukraine during 2002-2017. For the period 2002-2017 only 335 people arrived from Australia and Oceania.

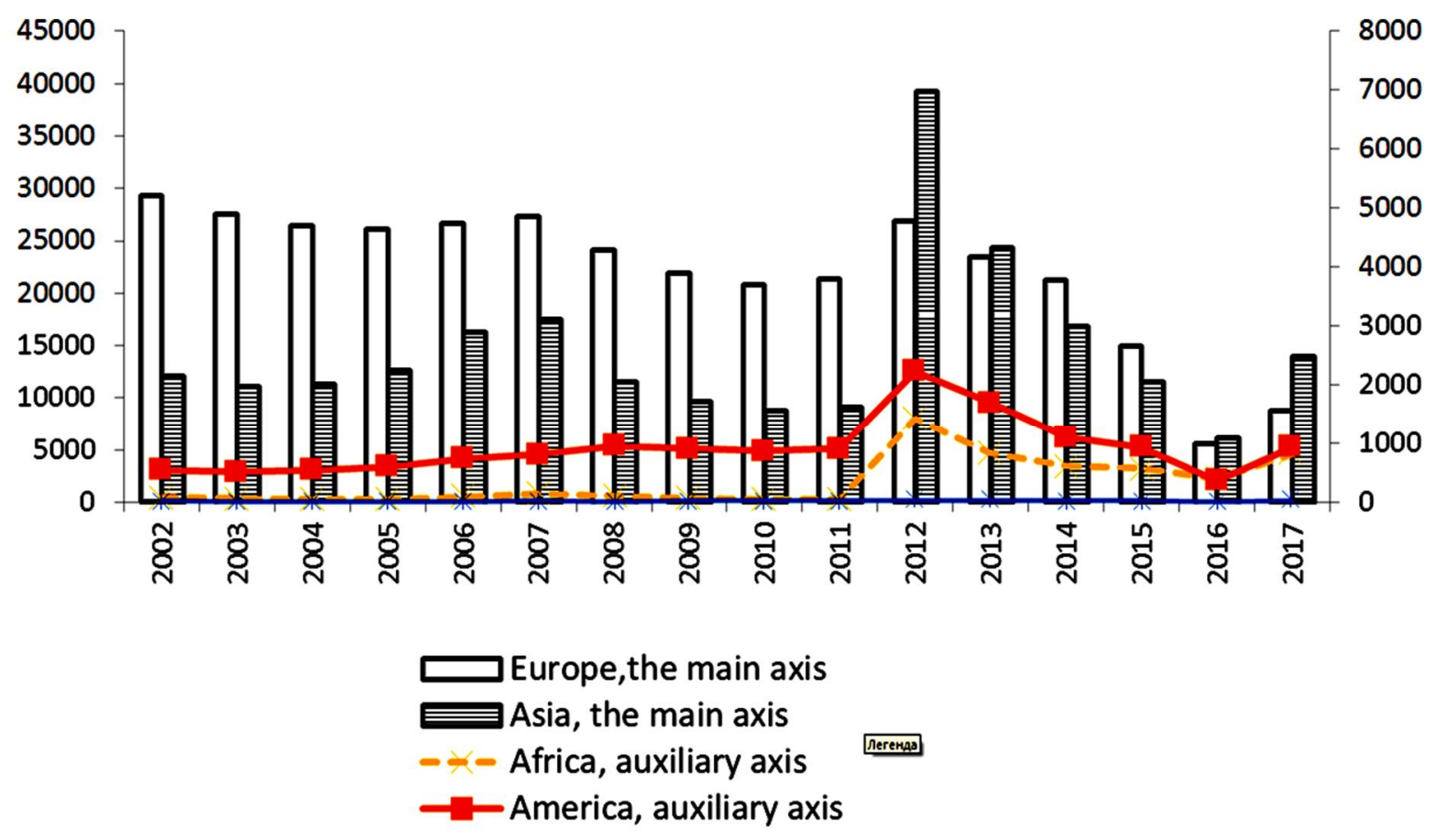

Fig. 3. Number of people arriving in Ukraine during 2002-2017 [17] 


\section{I. Halkiv, L. M. Prokopyshyn-Rashkevych}

The geographical structure of departure from Ukraine is slightly different from the arrival structure. Despite the fact that the majority of people left for European countries, the indicator of the share of this continent's countries in the composition of immigrants is inferior to the expatriate ratio by 15.2 p.p. The latter averaged $71.2 \%$, showing a downward trend (Table 1, Fig. 4). Asia is in the second place by the departure volume. This continent's share in the emigration flow averaged $17.5 \%$ and showed an upward trend. America ranks third in terms of arrival, where more than 42.400 people left during the period 2002-2017. Africa is almost five times inferior to it. The share of Australia and Oceania was $0.1 \%$ of the total number of emigrants.

Table 1

Geographical structure of international migrants in Ukraine [17]

\begin{tabular}{|c|c|c|c|c|c|c|c|c|c|c|c|c|c|c|c|}
\hline & \multicolumn{10}{|c|}{ Share of countries' groups, $\%$} & \multirow{2}{*}{\multicolumn{5}{|c|}{ Structure deviation by countries, p.p. }} \\
\hline & \multicolumn{5}{|c|}{ entry } & \multicolumn{5}{|c|}{ departure } & & & & & \\
\hline & 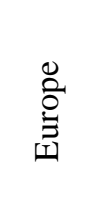 & 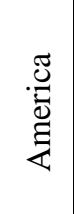 & $\frac{\cdot \pi}{2}$ & $\stackrel{\mathscr{E}}{\&}$ & 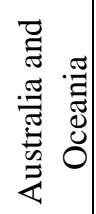 & 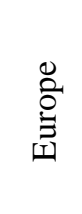 & 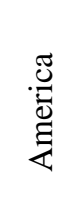 & $\frac{\cdot \pi}{2}$ & $\stackrel{\mathscr{E}}{\mathscr{Z}}$ & 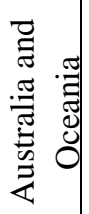 & 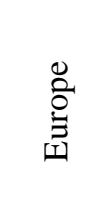 & 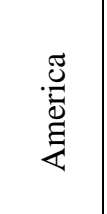 & $\frac{\frac{\pi}{2}}{2}$ & $\stackrel{\Xi}{\mathbb{Z}}$ & 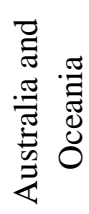 \\
\hline 2002 & 69.0 & 1.3 & 28.5 & 1.2 & 0.0 & 80.2 & 9.6 & 9.8 & 0.3 & 0.1 & -11.2 & -8.3 & 18.7 & 0.9 & -0.1 \\
\hline 2003 & 69.8 & 1.3 & 28.0 & 0.9 & 0.0 & 79.9 & 11.3 & 8.3 & 0.4 & 0.1 & -10.1 & -10.0 & 19.7 & 0.5 & -0.1 \\
\hline 2004 & 68.7 & 1.4 & 29.3 & 0.6 & 0.0 & 80.4 & 9.6 & 9.4 & 0.5 & 0.1 & -11.7 & -8.2 & 19.9 & 0.1 & -0.1 \\
\hline 2005 & 65.9 & 1.5 & 31.9 & 0.6 & 0.0 & 77.7 & 11.1 & 10.6 & 0.5 & 0.2 & -11.8 & -9.6 & 21.3 & 0.1 & -0.2 \\
\hline 2006 & 60.2 & 1.7 & 36.8 & 1.2 & 0.0 & 80.7 & 9.3 & 9.5 & 0.4 & 0.1 & -20.5 & -7.6 & 27.3 & 0.8 & -0.1 \\
\hline 2007 & $\begin{array}{l}58.8 \\
\end{array}$ & \begin{tabular}{ll|}
1.8 \\
\end{tabular} & 37.7 & 1.7 & 0.1 & 80.3 & $\begin{array}{l}9.4 \\
\end{array}$ & 9.5 & 0.7 & 0.1 & -21.5 & -7.6 & 28.2 & 1.0 & 0.0 \\
\hline 2008 & 64.8 & 2.6 & 30.9 & 1.8 & 0.0 & 77.7 & 8.1 & 12.7 & 1.3 & 0.1 & -12.9 & -5.5 & 18.2 & 0.5 & -0.1 \\
\hline 2009 & 66.6 & 2.8 & 29.4 & 1.2 & 0.1 & 76.9 & 7.4 & 14.4 & 1.3 & 0.1 & -10.3 & -4.6 & 15.0 & \begin{tabular}{l|l}
-0.1 \\
\end{tabular} & 0.0 \\
\hline 2010 & 67.7 & 2.9 & 28.5 & 0.9 & 0.1 & 77.1 & 7.7 & 14.8 & 0.2 & 0.2 & -9.4 & -4.8 & 13.7 & 0.7 & -0.1 \\
\hline 2011 & 67.5 & 2.9 & 28.6 & 0.9 & 0.1 & 69.7 & 8.4 & 21.0 & 0.8 & 0.1 & -2.2 & -5.5 & 7.6 & 0.1 & 0.0 \\
\hline 2012 & 35.1 & 2.9 & 51.5 & 10.4 & 0.0 & 67.3 & 6.1 & 24.6 & 1.8 & 0.2 & -32.2 & -3.2 & 26.9 & 8.6 & -0.2 \\
\hline 2013 & 43.3 & 3.1 & 45.0 & 8.6 & 0.1 & 47.7 & 4.7 & 41.5 & 6.0 & \begin{tabular}{l|l}
0.0 \\
\end{tabular} & -4.4 & -1.6 & 3.5 & 2.6 & 0.1 \\
\hline 2014 & 49.7 & 2.6 & 39.5 & 8.2 & 0.0 & 4.6 & 8.3 & 41.8 & 6.3 & 0.1 & 6.1 & -5.7 & -2.3 & 1.9 & -0.1 \\
\hline 2015 & 48.7 & 3.0 & 37.6 & 10.5 & 0.1 & 41.4 & 7.9 & 44.6 & 5.9 & 0.1 & 7.3 & -4.9 & -7.0 & 4.6 & 0.0 \\
\hline 2016 & 39.1 & 2.6 & 42.5 & 15.8 & 0.1 & 46.8 & 15.5 & 32.6 & 4.9 & 0.1 & -7.7 & -12.9 & 9.9 & 10.9 & 0.0 \\
\hline 2017 & 31.0 & 3.3 & 49.3 & 16.3 & 0.1 & 31.3 & 10.0 & 46.3 & 12.3 & 0.1 & -0.3 & -6.7 & 3.0 & 4.0 & 0.0 \\
\hline $\begin{array}{l}\text { For the } \\
\text { period } \\
2002- \\
2017\end{array}$ & 55.9 & 2.3 & 36.8 & 4.8 & 0.1 & 71.2 & 9.3 & 17.5 & 1.9 & 0.1 & -15.3 & -7.0 & 19.3 & 2.9 & 0.0 \\
\hline
\end{tabular}

So, the analysis of the State Statistics Service's data revealed that Europe and Asia have the greatest influence on Ukraine's migration changes. The share of European countries in the flow of both immigrants and emigrants is showing a downward trend, while of Asian countries is increasing. If America ranks third in the outflow and is almost five times ahead of Africa, in the inward flow it ranks fourth and is inferior twice. Canada and the USA provided between $78.1 \%$ and $93.3 \%$ of immigrants to Ukraine from the countries of America during 2010-2017, with the United States ranging from $67.8 \%$ to $84.5 \%$.

Significant differences between the regions of Ukraine regarding the settling of foreign nationals are rooted. Traditionally, immigration reaches the highest volume in the capital (in Kyiv) and the capital area, in Kharkiv, and Odesa regions. The increased level of immigration activity of the regions is related to their high economic potential and favorable situation in the labor market. 


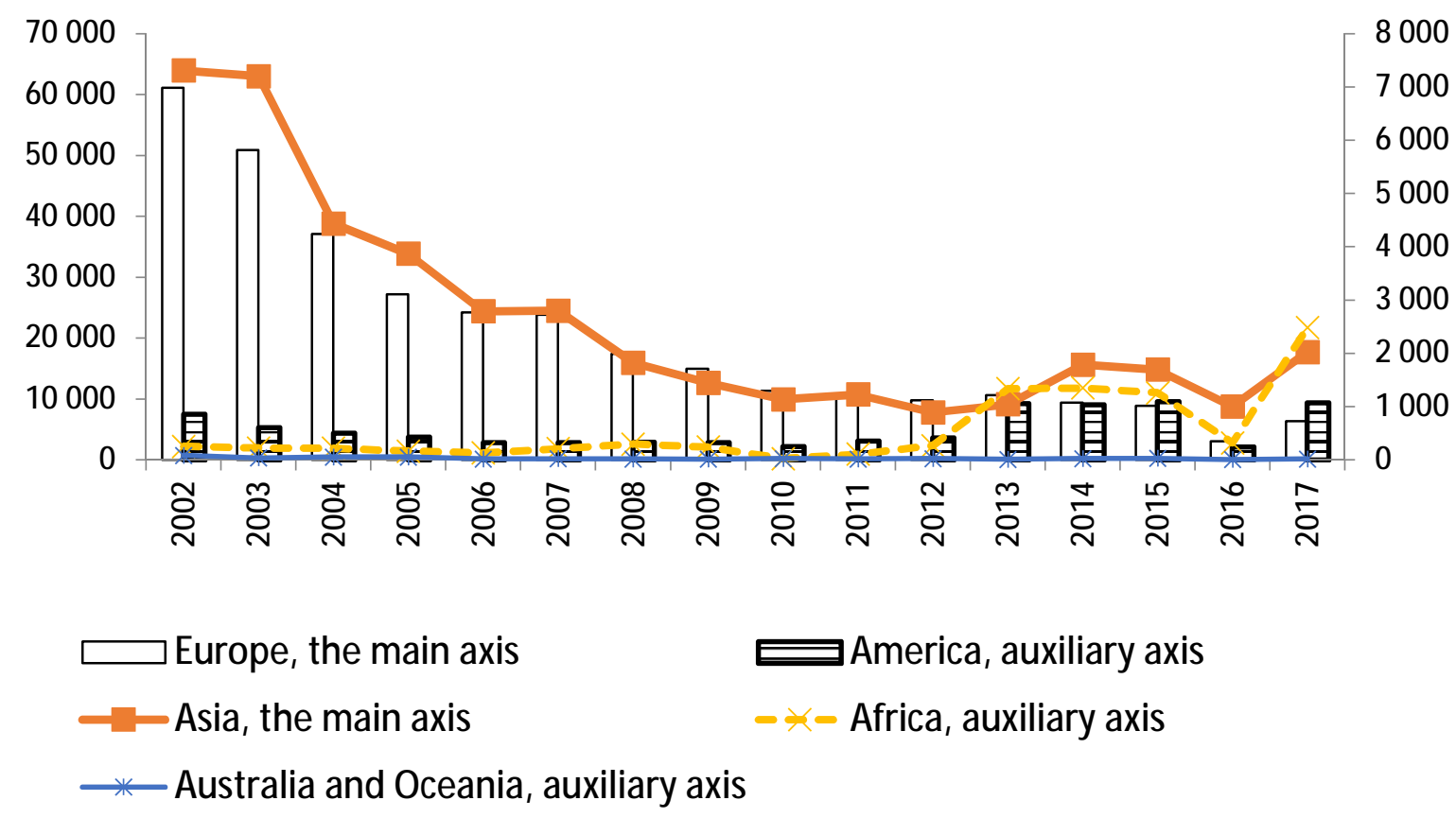

Fig. 4. Number of people who left Ukraine during 2002-2017, people [17]

The analysis of the gender structure of immigrants indicates the predominance in men (Fig. 5) (Demographic Yearbook, 2017). Thus, in 2017, their total number (19.154 people) exceeded twice the number of women ( 9.206 people). The distribution of immigrants by age indicates the dominant position of young people: in 2017, 65.4\% of immigrants accounted for the age group of 15-34 years. The share of this age group for men was $68.3 \%$, for women $-59.5 \%$.

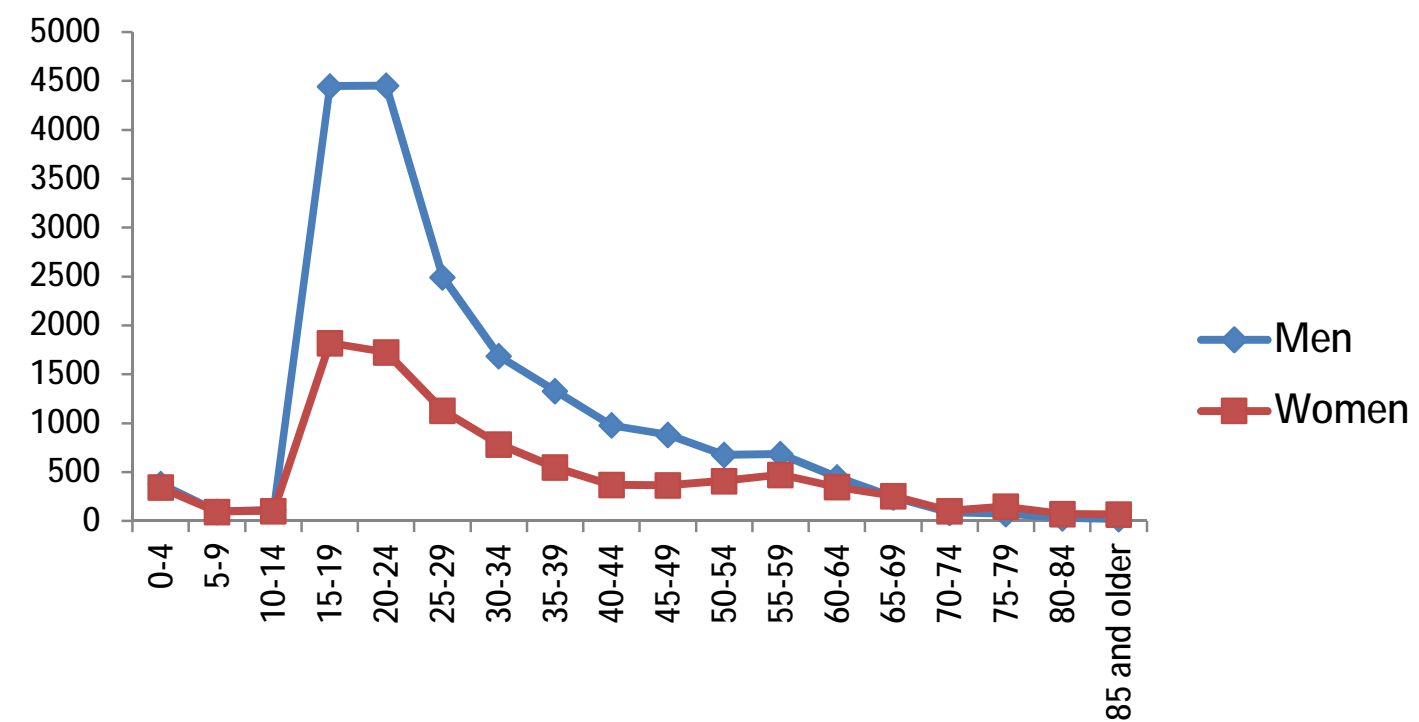

Fig. 5. Number of immigrants in Ukraine by age groups and sex in 2017, people [17]

The comparison of the number of immigrants of pre-working age, determined in Ukraine at the level of 0-14 years, to the number of immigrants of working age, which in Ukraine covers the age group of 60 years and older, indicates the prevalence of the latter. In 2017, the share of immigrants in the post-working age was $6.8 \%$, which 2.8 p.p. exceeds the share of immigrants of working age. This situation exacerbates the tendency for the population of Ukraine to age. The trend models of the age structure of the population for the period 1991-2018, built by the authors, show that the share of permanent population aged 0-14 


\section{I. Halkiv, L. M. Prokopyshyn-Rashkevych}

years decreases annually by more than 0.2 p.p. $\left(Y_{0-14}=-0,274 \times t+20,964 ; R^{2}=0,759\right)$, while at the age of 60 or older it increases by more than 0.1 p.p. $\left(Y_{60+}=0,140 \times t+18,384 ; R^{2}=0,811\right)$. Such changes are observed against the background of an annual decrease in the number of permanent population: if in the early 1990s it was 51.6 million people, at the beginning of 2019 (excluding the annexed Crimea and the occupied territory in the east) -42.0 million people. The long-term forecast indicates a further demographic decline in Ukraine: 2030-41.2 million people; 2050 - 36.4 million people; $2100-28.2$ million people (World Population Prospects, 2017).

One of the socio-cultural factors of migration attraction is education quality. The total number of foreign students in Ukraine in recent years exceeds 50 thousand people annually. Technical and medical institutions of higher education are the most popular among foreign students. Against the background of a decrease in the number of domestic students (including due to an increase in outflows abroad), the share of foreign students in the educational environment of Ukraine is increasing (Table 2) [17].

Table 2

Selected indicators of educational immigration in Ukraine

\begin{tabular}{|c|c|c|c|c|c|c|}
\hline & 2012 & 2013 & 2014 & 2015 & 2016 & 2017 \\
\hline Number of foreign students in Ukraine, thousand people & 43.6 & 49.6 & 60.0 & 57.6 & 54.1 & 52.8 \\
\hline $\begin{array}{l}\text { Deviation of the number of Ukrainian students abroad from the } \\
\text { number of foreign students in Ukraine, thousand people }\end{array}$ & -6.2 & -7.2 & -10.1 & 10.7 & 22.1 & 24.4 \\
\hline $\begin{array}{l}\text { Ratio of foreign students in Ukraine to the total number of students in } \\
\text { Ukraine, } \%\end{array}$ & 1.8 & 2.3 & 2.8 & 3.2 & 3.2 & 3.3 \\
\hline
\end{tabular}

The immigration statistics in Ukraine is not developed pretty well because of complexity and maintenance by various institutions and poor cooperation and coordination between them. The census can provide a comprehensive assessment of immigration in accordance with important socio-demographic characteristics. This would allow obtaining relevant information on immigrants through specially organized random sampling.

\section{Conclusions}

Effective migration management is designed to provide a solid foundation for stabilizing the turbulence of the modern world. This is achieved by usage the migration potential for development, preventing its risks, reducing its negative consequences. The scientific and social discourse in Ukraine tends to be a problem of emigration, since the outflow of human capital abroad, having gained significant volumes, creates an appreciable impact on economic, social, demographic and political processes in the country.

\section{Prospects for further research}

Prospects for further research are to expand the geographical space, statistical indicators, management levers and other aspects of migration management. It is worth developing constructive proposals on the possibility of adapting the best practices of migration management in accordance with the Ukrainian realities.

1. Гречко О. Ю. (2017). Теоретико-концептуальні засади вивчення державної міграційної політики: вітчизняний та закордонний досвід. Гілея: науковий вісник, Вип. 119, С. 350-354.

2.Риндзак О. Т. (2019). Міграційна політика в Україні: виклики та перспективи: монографія. Львів: ІРД НАН України, С. 424.

3. Садова У. Я. (2015). Наслідки міграційних процесів: нові виклики та можливості для регіонів. НАН України, ДУ “Інститут регіональних досліджень імені М. І. Долішнього”. Львів, 252 с.

4. Стаканов Р. Д. (2017). Виклики регіональної міграційної політики. Вісник Хмельницького національного університету, № 5, С. 125-128.

5. Сухорукова Л. М. (2015). Миграционный менеджмент в образовании: Основные исследовательские задачи. Культура. Наука. Интеграичия, С. 9-14.

6. Hollifield, J. F. (2004). The Emerging Migration State. The International Migration Review, Vol. 38, No. 3, Conceptual and Methodological Developments in the Study of International Migration, pp. 885-912. 


\section{Migration management: analytical and statistical data on migration in Ukraine}

7. Міжнародна термінологія у сфері міграції: українсько-англійський тлумачний словник (2015). К.: Міжнародна організація з міграції, $100 \mathrm{c}$.

8. Held Tobias, Conrad Christian (2014). The Politics of International Migration and its Management Conception. Available at: https://migrablog.wordpress.com/2014/10/08/the-politics-of-international-migration-andits-management-conception-3/.

9. Summary of the report of the Global Commission on International Migration. Global Commission on International Migration. Available at: http://www.un.org/esa/population/meetings/ fourthcoord2005/P09_GCIM.pdf.

10. Olena Malynovska (2016). Migration in Ukraine: Facts and figures. The International Organization for Migration (IOM), $32 \mathrm{p}$.

11. Федерко Н., Нестерова I. (2019). Зовнішня трудова міграція та стан ринку праці в Україні. Available at: https://ir.kneu.edu.ua/bitstream/handle/2010/30348/MO_2019_5.pdf?sequence=1\&isAllowed=y (C. 80-101)

12. Дмитрук Б. П. (2015). Міжнародна міграція: тенденції, причини, наслідки. Проблеми вдосконалення економіко-правової системи України на сучасному етапі розвитку громадянського суспільства: тези доповідей учасників Всеукраїнської науково-практичної конференції. Черкаси. Східноєвропейський університет економіки і менеджменту, С. 189-192.

13. Петроє О. (2017). Міжнародна трудова міграція: аналіз ситуації та наслідків для України. Вісник Національної академії державного управління при Президентові України. Серія: Державне управління, №. 4, C. 93-100. Available at: http://nbuv.gov.ua/UJRN/ Vnadu_2017_4_16.

14. Чорна В. О. (2016). Динаміка міграційних процесів в Україні: соціологічний аналіз. Наукові праці Чорноморського державного університету імені Петра Могили. Серія: Соціологія, Т. 258, Вип. 246, С. $175-180$.

15. Ровенчак О. (2005). Проблема вивчення міграції та зв'язку з процесами глобалізації в соціології. Вісник Одеського національного університету, №. 4, С. 35-43.

16. Населення. Статистична інформація (2020). Державна служба статистики України. http://www.ukrstat.gov.ua/

17. Демографічний щорічник (2017). Державна служба статистики України, 2018, 138 с.

18. Закон України "Про правовий статус іноземців та осіб без громадянства" (2012). Biдомості Верховної Ради України, № 19-20. Available at: https://zakon.rada.gov.ua/laws/show/3773-17.

1. Grechko O. Yu. (2017). Theoretical and conceptual principles of studying the state migration policy: domestic and foreign experience. Gilea: scientific bulletin, Issue 119, pp. 350-354.

2.Rindzak O. T. (2019). Migration policy in Ukraine: Challenges and prospects: a monograph. Lviv: IRD NAN of Ukraine, $424 \mathrm{p}$.

3. Sadova U. Ya. (2015). Consequences of migration processes: new challenges and opportunities for regions. NAS Ukraine, State Institution “Institute of Regional Research named after M. I. Dolishniy”. Lviv, 252 p.

4. Stakanov R. D (2017). Challenges of regional migration policy. Bulletin of Khmelnytsky National University, No. 5, pp. 125-128.

5. Sukhorukova L. M. (2015). Migration management in education: Basic research objectives. Culture. Science. Integration, pp. 9-14.

6. Hollifield J. F. (2004). The Emerging Migration State. The International Migration Review, Vol. 38, No. 3, Conceptual and Methodological Developments in the Study of International Migration, pp. 885-912.

7. International terminology in the field of migration. Ukrainian-English explanatory dictionary (2015). K.: International Organization for Migration, $100 \mathrm{p}$.

8. Held Tobias, Conrad Christian (2014). The Politics of International Migration and its Management Conception. URL: https://migrablog.wordpress.com/2014/10/08/the-politics-of-international-migration-and-itsmanagement-conception-3/.

9. Summary of the report of the Global Commission on International Migration. Global Commission on International Migration URL: http://www.un.org/esa/population/meetings/ fourthcoord2005/P09_GCIM.pdf.

10. Malynovska Olena (2016). Migration in Ukraine: Facts and figures. The International Organization for Migration (IOM), $32 \mathrm{p}$.

11. Federko N., Nesterova I. (2019). External labor migration and the state of the labor market in Ukraine. URL: https://ir.kneu.edu.ua/bitstream/handle/2010/30348/MO_2019_5.pdf?sequence=1\&isAllowed=y (P. 80-101)

12. Dmitruk B. P. (2015). International migration: trends, causes, consequences. Problems of improving the economic and legal system of Ukraine at the present stage of development of civil society: abstracts of reports of participants of the Ukrainian scientific-practical conference. Cherkasy. Eastern European University of Economics and Management, pp. 189-192.

13. Petro O. (2017). International labor migration: analysis of the situation and consequences for Ukraine. Bulletin of the National Academy of Public Administration under the President of Ukraine. Series: Public Administration, No. 4, S. 93-100. URL: http://nbuv.gov.ua/UJRN/ Vnadu_2017_4_16. 


\section{I. Halkiv, L. M. Prokopyshyn-Rashkevych}

14. Chorna V. O. (2016). Dynamics of migration processes in Ukraine: a sociological analysis. Scientific works of the Black Sea State University named after Petro Mohyla. Series: Sociology, T. 258, Issue 246, pp. 175-180.

15. Rovenchak O. (2005). The problem of studying migration and its connection to the processes of globalization in sociology. Bulletin of Odessa National University, No. 4, pp. 35-43.

16. Population of Ukraine (2020). State Statistics Service of Ukraine. Retrieved from https://http://www.ukrstat.gov.ua/

17. Demographic Yearbook (2017). State Statistics Service of Ukraine. Kyiv, 138 p.

18. The Law of Ukraine "The Legal Status of Foreigners and Stateless Persons". Available at: https://zakon.rada.gov.ua/laws/show/3773-17.

Л. І. Гальків, Л. М. Прокопишин-Рашкевич Національний університет “Львівська політехніка”, кафедра менеджменту організацій

\section{МІГРАЦІЙНИЙ МЕНЕДЖМЕНТ: АНАЛІТИЧНІ ТА СТАТИСТИЧНІ ДАНІ ПРО МІГРАЦІЮ В УКРАЇНІ}

\section{(ㄱ Гальків Л. І., Прокопишин-Рашкевич Л. М., 2020}

Вироблення спільних управлінських рішень, націлених на керованість, передбачуваність та корисність міграційних процесів, потребує пізнання нового наукового напряму - міграційного менеджменту. Ефективний міграційний менеджмент покликаний забезпечувати створення міцного фундаменту для стабілізації турбулентності сучасного світу. Це досягається завдяки використанню потенціалу міграції для розвитку, запобіганню ії ризикам, зменшенню її негативних наслідків. Тому автори актуалізують необхідність визначення міграційного менеджменту та основних етапів національної міграції населення в Україні.

Управління міграцією може мати позитивне значення $\mathbf{i}$ для країн походження, $\mathbf{i}$ для країн призначення, i для самих мігрантів. У структурі цієї концепції виокремлено три складові: суб'єкти, практики та дискурси. Міграційний менеджмент розглядається як ринкова система вирішення проблем, пов'язаних із міграцісю населення, де держави можуть купити певне рішення. Тобто йдеться про отримання урядами держав рекомендацій та сценаріїв міграційної політики від міжнародних організацій на основі досліджень, проведених у цих державах.

Науковий і суспільний дискурс в Україні тяжіс до проблем еміграції, оскільки відтік людського капіталу за кордон, набувши значних обсягів, відчутно впливає на економічні, соціальні, демографічні й політичні процеси в крайні. Дослідження становища іммігрантів в Україні зазвичай реалізуються під патронатом міжнародних інституцій за участю громадських організацій.

Проблема оцінювання параметрів імміграції зумовлена браком офіційної статистичної інформації. Статистику цього процесу ведуть різні інституції. Співпраця та координація дій міністерств і відомств у галузі імміграційної статистики низькі.

Імміграційна політика України перебуває у стані формування, а її нормативно-правова база перманентно вдосконалюється. Проблема оцінювання кількості іммігрантів для України типова, як і для низки інших держав. Це зумовлено не тільки поширенням нелегальних потоків мігрантів та (чи) незаконним перебуванням окремих осіб після закінчення терміну дії візи, але й відмінністю правових форм перебування (постійне проживання, тимчасове проживання, перебування іноземців, які користуються міжнародним захистом та навчаються).

Рівень імміграції в Україні залишається невисоким. Іноземці нерідко розглядають Украӥну не як бажане місце проживання, а як транзитну територію, зручний коридор на шляху до омріяної мети - проживання в Європі. Через територію України проходить один із п'яти основних маршрутів нелегальної міграції до держав Західної Європи - центральносвропейський, який пролягає через Російську Федерацію, Україну, Польщу, Словаччину. Водночас транзитні міграційні потоки через Україну не впливають істотно на міграційну ситуацію у ЄС.

Визначені числові характеристики, динамічні моделі та етапи міграційних змін населення віддзеркалюють окремі аспекти міграційного менеджменту в Україні.

Ключові слова: міграція; міграційний менеджмент; імміграційна статистика; міграційна політика в Україні. 